J. Clin. Chem. Clin. Biochem.

Vol. 18, 1980, pp. 197-208

\title{
Enzyme Immunoassays in Clinical Chemistry: Present Status and Trends ${ }^{1}$ )
}

\author{
By M. Oellerich
}

\section{Institut für Klinische Chemie \\ Medizinische Hochschule Hannover}

(Received September 29/December 21, 1979)

Summary: The most important enzyme immunoassay techniques are described. The enzymes currently used as labels, the methods of coupling them to antigens or haptens and the possible applications of these assays are reviewed. Furthermore, an overview is given of the reliability and practicability of commercially available enzyme immunoassay kits used in clinical chemical laboratories. Special consideration is given to possible interferences, the detection limits and the mechanization of these tests. Various methods for curve-fitting are listed. It is concluded that most of the currently commercially available enzyme immunoassays are suitable for routine application in appropriate centers like clinical chemical laboratories of larger hospitals. The future role of enzyme immunoassays in clinical chemistry is briefly discussed.

\section{Enzymimmunotests in der Klinischen Chemie: Gegenwärtiger Stand und Entwicklungstendenzen}

Zusammenfassung: Die wichtigsten Techniken des Enzymimmunotests werden beschrieben. Es wird eine Übersicht über die gegenwärtig zur Markierung verwendeten Enzyme, die Methoden zu deren Kopplung an Antigene oder Haptene und die Anwendungsmöglichkeiten dieser Tests gegeben. Ferner wird über den gegenwärtigen Stand der Zuverlässigkeit und Praktikabilität von käuflichen Enzymimmunotests berichtet, welche in klinisch-chemischen Laboratorien angewendet werden. Besondere Berücksichtigung finden die möglichen Interferenzen, die Nachweisgrenzen und Verfahren zur Mechanisierung dieser Tests. Verschiedene mathematische Methoden zur Ermittlung der Ergebniswerte sind aufgeführt. Es wird gefolgert, daß die meisten der zur Zeit käuflichen Enzymimmunotests für die routinemäßige Anwendung in geeigneten Zentren, wie z. B. klinisch-chemischen Laboratorien größerer Kliniken, geeignet sind. Die zukünftige Rolle der Enzymimmunotests in der Klinischen Chemie wird kurz diskutiert.

\section{Introduction}

Since the development of the first radioimmunoassay by Yalow \& Berson (1) twenty years ago, immunological techniques using labeled reactants have gained an extraordinary importance in the field of medical research and in routine diagnosis. Because of its high sensitivity and specificity the radioimmunoassay has already found a broad area of application and has contributed, especially in endocrinology, to a decisive improvement of clinical diagnosiss.

In recent years the usefulnèss of many other markers such as enzymes $(2-4)$, a coenzyme $(5-6)$, a fluorogenic substrate (7-9), fluorescent dyes (10-13), chemilumininescence producing compounds (14), a luminol reactive heme containing compound (15), stable free radicals (16), bacteriophages (17) and polystyrene beads

\footnotetext{
1) Extended version of a plenary lecture held at the Joint Annual Meeting of the Austrian Society and German Society for Clinical Chemistry at Salzbuig 1979.
}

(174) - has been investigated. The enzyme immunoassay in particular has proved to be an especially suitable alternative to radioimmunoassay. Compared with the radioimmunoassay this procedure has the advantage that there is no contact with radioactive material, larger clinical chemical laboratories can use their standard equipment, and the reagents have a much longer shelflife. There are several reviews dealing with enzyme immunoassay $(18-26,175)$. The purpose of this paper is to review the assay principles, precision, accuracy, specificity, detectability and practicability of enzyme immunoassays currently available for routine use in clinical chemical laboratories.

\section{Assay principles}

Various techniques of the enzyme immunoassay have been developed. Since the great number of described modifications of this procedure renders a survey difficult, an attempt has been made in figure 1 and 2 to give a 
Antibody-induced inactivation of the enzyme

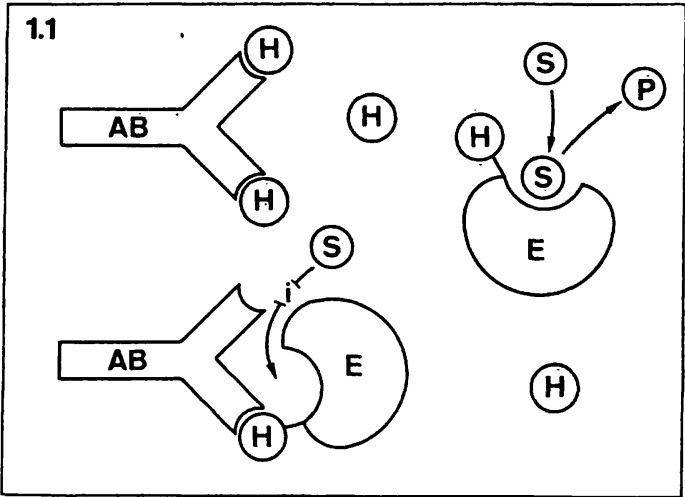

Antibody-induced reactivation of the enzyme

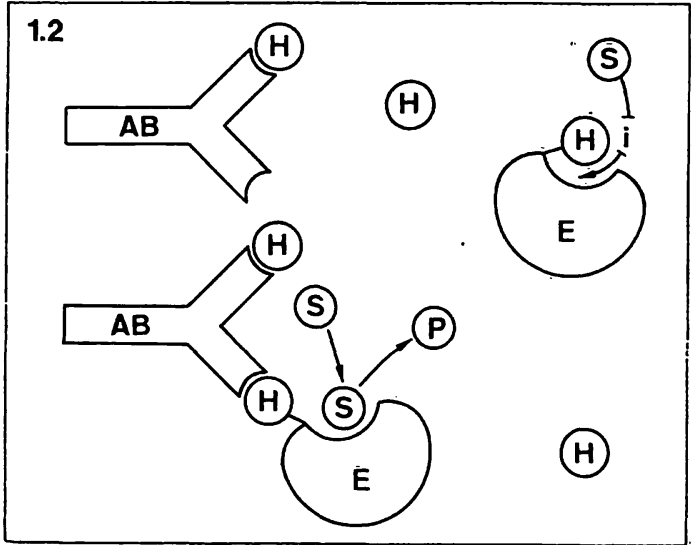

Fig. 1. Principles of the homogeneous enzyme immunoassays (EMIT). All reactants are present in one reaction medium. $H$ hapten, E-H enzyme labeled hapten, $A B$ limited amount of antibody, $\mathrm{i}$ inhibition of the "marker enzyme", S substrate and P product of the enzymic reaction.
Competitive enzyme immunoàssay
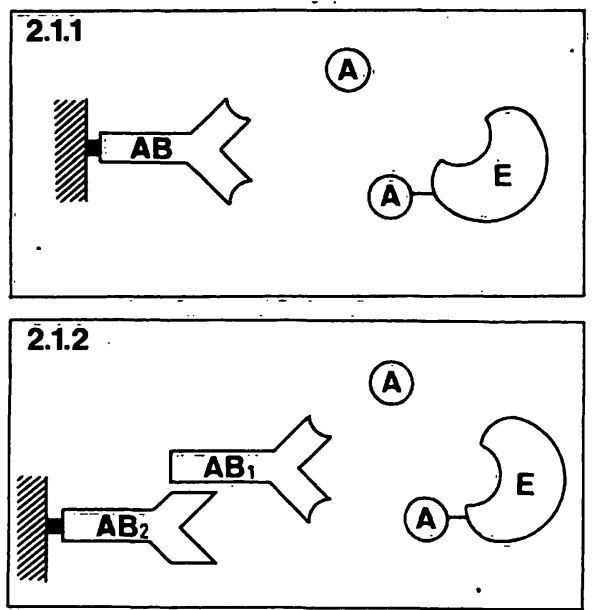

Immuno-enzymometric assay $\mathbf{2 . 2}$

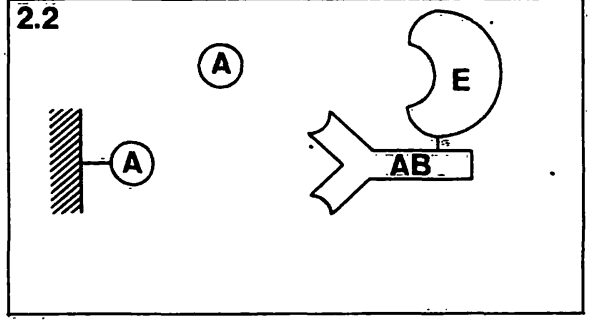

Competitive sandwich assay

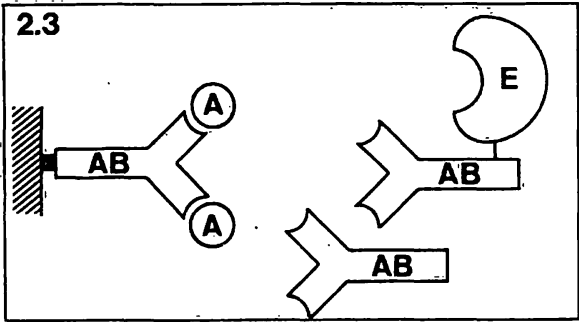

Sandwich antigen assay
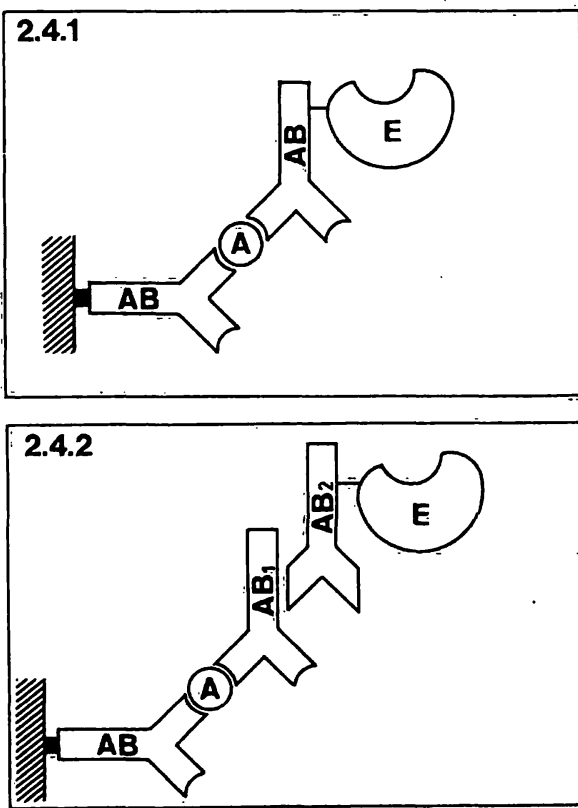

Sandwich antibody assay.

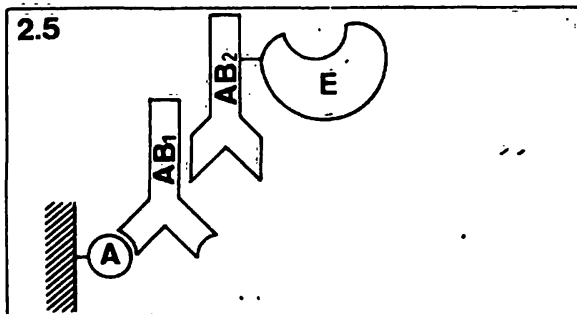

Fig. 2. Principles of heterogeneous enzyme immunoassays (ELISA).

$A$ antigen, E-A enzyme labeled antigen, E-AB enzyme labeled antibody, $A B$ and $A B_{1}$ antibody against antigen or hapten under test, $\mathrm{AB}_{2}$ antibody directed against the immunoglobulin of the species, which was immunized with the antigen to be determined. 
classification and schematic representation of the most important assay principles.

Competitive procedures, in which a separation step is avoided, are referred to as homogeneous enzyme immunoassays. In these tests, which are commercially available under the trade name "EMIT"2), the enzymatic activity of the hapten-enzyme conjugate is influenced by the antigen-antibody reaction (4). In the first type of these assays (fig. 1.1) the activity of the marker enzyme is reduced, if the hapten-enzyme conjugate is coupled to the antibody.

It is assumed that the antibody reduces the affinity of the substrate to the active site of the enzyme, either by steric hindrance (fig. 1.1) or by a conformational change of the enzyme, or by prevention of conformational changes necessary for catalytic activity $(4,20,21,27)$. A further procedure of the EMIT is based on an inhibition of the marker enzyme by the coupled hapten (fig. 1.2). The marker enzyme is reactivated, if the antibody to the corresponding hapten is bound to the hapten-enzyme conjugate. So far this technique has only been used for the determination of thyroxine (28).

With both procedures the enzyme activity determined depends on the concentration of the free hapten in the sample. The technique of the homogeneous enzyme immunoassay is suitable especially for the detection of haptens. Therefore these assays are widely used particularly for drug monitoring and the determination of thyroxine. Recently, however, this principle was also used for the detection of large molecules such as staphylococcal enterotoxin B (29), immunoglobulins (IgG, IgM) and serum albumin (30).

Other competitive procedures, in which coenzymes are used to label the ligand $(5,6)$, may also be classified as homogeneous enzyme immunoassays. If the ligand-coenzyme conjugate is bound to an antibody, its cycling in a suitable enzymic cycle is proportionally reduced. This inhibition is reversed by unconjugated ligands in competitive binding reactions. The cycling rates are determined by spectrophotometric measurement of a reaction product (5), or of the unbound ligand-coenzyme conjugate by a highly sensitive bioluminescent reaction employing luciferase (EC 1.2.0.0.) from photobacterium fisheri (6). So far, however, this assay principle has gained no significance in clinical diagnosis.

Assay systems, in which the enzymic activity of the conjugate is not influenced by the antigen-antibodyreaction, require a separation step and are called heterogeneous enzyme immunoassays; if solid-phase systems are used for the separation of free and bound labeled molecules, the procedure is called an enzyme-linked immunosorbent assay (ELISA). These procedures allow the determination of haptens and antigens.

2) EMIT $^{\circledR}$ : enzyme multiplied immunoassay technique.
The competitive enzyme immunoassay (fig. 2.1.1) is analogous to the well known classical radioimmunoassay of Yalow \& Berson (1). Labeled and unlabeled antigens compete for the binding sites of a limited amount of antibody. As in the competitive homogeneous enzyme immunoassay, saturation of the antibody occurs simultaneously, providing all reactants are incubated together. This procedure is used with several commercial tests: for example, in the ENZYMUN ${ }^{3}$ ) digoxin and thyroxine assays $(31,32)$.

The principle of "sequential saturation" is preferred under certain conditions, e. g. if antigens with very low serum concentrations such as insulin and thyrotropin are to be determined (33-35). According to Pratt et al. this technique, however, leads to reduced specificity (36).

Owing to the size and other properties of the enzyme label relative to the antigen or antibody, the systems used are mostly solid-phase; for example, antibody coated polystyrene tubes, cellulose and recently also magnetic polyacrylamide agarose particles have been used for the separation of bound and free enzyme-conjugate $(21,22,37)$.

Recently an enzyme immunoassay for the determination of thyrotropin has been developed $(35,179)$, in which the immune complex formed is precipitated by a second antibody. If the second antibody used for the separation step is bound to a solid phase (fig. 2.1.2), the procedure is called a double antibody solid phase (DASP) technique (177).

Procedures in which the sample antigen is bound to an enzyme-labeled antibody added in excess, are classified as immuno-enzymometric assays (fig. 2.2). The remaining, free labeled antibody is separated by binding with antigen coupled to a solid phase, which is added in excess.

In a further procedure, which has also been called a competitive "sandwich" assay (26), labeled and unlabeled antibody compete for the binding to an antigen, which is bound to an antibody attached to a solid phase (fig. 2.3). This method is used for the detection of antibodies against $\mathrm{HB}_{\mathrm{s}}$-antigen (22).

Non-competitive "sandwich" assays have been described in numerous modifications (26). In the following only the two most common techniques will be briefly explained.

In the sandwich antigen assay an excess of antibody is bound to a solid phase (fig. 2.4.1). The binding of the antigen to the antibody is determined by use of labeled antibody of the same specificity; therefore, it is necessary that the antigen posses more than one antigenic determinant. Various commercial assays for the detection of $\mathrm{HB}_{\mathrm{s}}$-antigen and $\alpha_{1}$-fetoprotein are based on this technique.

3) ENZYMUN-TEST $^{\circledR}=$ trade name for various heterogeneous enzyme immunoassays. 
In a variation of this method, the bound antibody $\left(\mathrm{AB}_{1}\right)$ is indirectly labeled by a second enzyme-labeled antibody, which is directed against the first $\left(\mathrm{AB}_{1}\right)$ and should not react with the antibody $(A B)$ attached to the solid phase (fig. 2.4.2). The antibodies $A B_{1}$ and $A B$ should be obtained from different species. Such an indirect labelling can also be applied to the immunoenzymometric assay. The method of indirect labelling has the advantage, that the corresponding enzyme-antibody conjugates, for a relatively universal application, are commercially available. Thus the often difficult direct labelling of the antibody may be circumvented.

In the sandwich antibody assay, the antibody to be determined reacts with an antigen bound to the solid phase, and is detected by a second enzyme-labeled antibody.

\section{Enzymes used as labels}

The quality of an enzyme immunoassay depends very much on the purity of the antigen or hapten used for immunization, calibration and conjugation, the specificity of the antibody and the choice of a suitable enzyme label. Sensitive assays require a highly purified enzyme with a high turnover number, and a low detection limit for the reaction product (22).

The enzymes listed in table 1 and 2, which are mainly of vegetable and bacterial origin, have proved generally useful. The enzymes most frequently used so far for heterogeneous enzyme immunoassays are horse-radish peroxidase, alkaline phosphatase and $\beta=D$-galactosidase (tab. 1).

The determination of the enzyme activity is chiefly performed by photometry. In order to increase the

Tab. 1. Marker-enzymes for heterogeneous enzyme immunoassays (from data listed in 1. c. $(15,22,38-40)$ ).

\begin{tabular}{|c|c|c|c|}
\hline Enzyme & Source & Indicator & Analytical principlè \\
\hline \multirow[t]{2}{*}{$\begin{array}{l}\text { Peroxidase } \\
\text { (EC 1.11.1.7) }\end{array}$} & \multirow[t]{2}{*}{ Horse-radish } & $\begin{array}{l}\mathrm{H}_{2} \mathrm{O}_{2} \text { /chromogen } \\
\mathrm{H}_{2} \mathrm{O}_{2} \text { /pyrogallol or luminol, } \\
\text { photon }\end{array}$ & $\begin{array}{l}\text { Photometry } \\
\text { Luminescence measurement }\end{array}$ \\
\hline & & $\mathrm{H}_{2} \mathrm{O}_{2} / \mathrm{KI} / \Delta \mathrm{E}[\mathrm{mV}]$ & Potentiometry \\
\hline $\begin{array}{l}\text { Alkaline phosphatase } \\
\text { (EC 3.1.3.1) }\end{array}$ & $\begin{array}{l}\text { Calf intestine } \\
\text { E. coli }\end{array}$ & $p$-Nitrophenol & Photometry \\
\hline $\begin{array}{l}\beta-D-\text { Galactosidase } \\
\text { (EC 3.2.1.23) }\end{array}$ & E. coli & $\begin{array}{l}\text { o-Nitrophenol } \\
\text { 4-Methylumbelliferone }\end{array}$ & $\begin{array}{l}\text { Photometry } \\
\text { Fluorimetry }\end{array}$ \\
\hline $\begin{array}{l}\text { Glucoamylase } \\
\text { (EC 3.2.1.3) }\end{array}$ & Rhizopus niveus & Glucose/NADPH & Fluorimetry \\
\hline $\begin{array}{l}\text { Glucose oxidase } \\
\text { (EC 1.1.3.4) }\end{array}$ & Aspergillus niger & $\mathrm{H}_{2} \mathrm{O}_{2} /$ chromogen & Photometry \\
\hline $\begin{array}{l}\text { Acetylcholinesterase } \\
\text { (EC 3.1.1.7) }\end{array}$ & Electrophorus electricus & {$\left[{ }^{3} \mathrm{H}\right]$ Acetylcholin } & Scintillation spectrometry \\
\hline $\begin{array}{l}\text { Catalase } \\
(\text { EC 1.11.1.6) }\end{array}$ & Beef liver & $\mathrm{H}_{2} \mathrm{O}_{2}$ /enthalpy & Thermometry \\
\hline
\end{tabular}

Tab. 2. Marker-enzymes for homogeneous enzyme immunoassays (from data listed in l. c. $(22,29,30)$ ).

\begin{tabular}{llll}
\hline Enzyme & Source & Indicator & Analytical principle \\
\hline $\begin{array}{l}\text { Lysozyme } \\
\text { (EC 3.2.1.17) }\end{array}$ & Chicken egg-white & $\begin{array}{l}\text { Cell wall fragments of } \\
\text { Micrococcus luteus }\end{array}$ & Turbidimetry \\
$\begin{array}{l}\text { Malate dehydrogenase } \\
\text { (EC 1.1.1.37) }\end{array}$ & Pig-heatt mitochondria & NADH & Photometry \\
$\begin{array}{l}\text { Glucose-6-phosphate dehydrogenase } \\
\text { (EC 1.1.1.49) }\end{array}$ & Leuconostoc mesenteroides & NADH & Photometry \\
$\begin{array}{l}\text { p-D-Galactosidase } \\
\text { (EC 3.2.1.23) }\end{array}$ & E. coli & Chromogen & Photometry \\
$\begin{array}{l}\beta-A m y l a s e \\
\text { (EC 3.2.1.2) }\end{array}$ & Potato & Starch/reducing groups & Photometry \\
\hline
\end{tabular}


detectability of the assays, however, fluorogenic ( 41 , $42,176,177,180)$, radioactive (43) and chemiluminescence producing substrates (38) are also used. In a newly developed procedure, the activity of peroxidase bound to an antibody-coated membrane is determined by an iodide-sensitive electrode (39).

\section{A thermometric enzyme immunoassay with adequate} sensitivity was recently described, in which the enthalpy of the enzymic reaction is measured (40). In this assay, a continuous flow system with immobilized antibodies is used. At present this procedure has the disadvantage of a low throughput of 10-20 samples/day and a large specimen volume of $1 \mathrm{ml}$.

With the homogeneous enzyme immunoassays an NAD dependent glucose-6-phosphate dehydrogenase from Leuconostoc mesenteroides is mainly used. This enzyme can be easily determined photometrically (tab. 2). A turbidimetric procedure is applied for the determination of the activity of lysozyme in the semiquantitative EMIT for the detection of drug abuse (4). With the newly developed EMIT for the determination of proteins, $\beta$-galactosidase is used as the enzyme label, and a macromolecular chromogenic compound (not further described by the authors) serves as substrate (30).

\section{Coupling procedures}

The choice of a coupling method depends primarily on the molecule to be labeled. Enzyme-antigen or antibody conjugates are usually prepared by glutaraldehyde or periodate methods (22). The coupling of enzymes to haptens is mostly carried out by formation of a peptide bond between the carboxyl group of a hapten and an amino group of an enzyme by use of the carbodiimide or mixed anhydride method (22).

\section{Area of application}

The area of application of the enzyme immunoassay corresponds largely to that of the radioimmunoassay. Enzyme immunoassays can be performed with samples of serum, plasma, urine and saliva.

For the detection of various drugs and hormones, a number of commercial kits are already used in clinical chemical routine laboratories. Furthermore assays for the determination of plasma proteins, tumor antigens, antigens of pathogenic organisms and antibodies have been developed $(22,26)$.

\section{Imprecision}

The imprecision of enzyme immunoassays is of the same order of magnitude as that of corresponding radioimmunoassays. According to our experience with . most of the currently commercially available enzyme immunoassays coefficients of variation from day to day of about 2-10\% could be achieved in the medium measuring range, if duplicate determinations were performed (tab. 3). However, the use of partly or fully
Tab. 3. Imprecision from day to day with commercially available enzyme immunoassays.

\begin{tabular}{llll}
\hline Parameter & $\begin{array}{l}\text { Assay } \\
\text { principle of mechanization }\end{array}$ & $\begin{array}{l}\text { Degree } \\
\text { ofieffi- Ref. } \\
\text { cient of } \\
\text { variation } \\
(\%)\end{array}$ \\
\hline
\end{tabular}

Phenobarbital

Phenytoin

Carbamazepine EMIT Fully mechanized
Primidone

Ethosuximide

Theophylline

Methotrexate

Lidocaine

EMIT Fully mechanized

EMIT Fully mechanized

$2-16$

46

Digoxin

Thyroxine

Binding Index

$\alpha_{1}$-Fetoprotein

Insulin

Carcino-

Partly mechanized

embryonic

antigen

Triiodo-

thyronine
Partly mechanized

3

EMIT Partly mechanized

4- 7

4-10

$3-12$

ELISA Partly mechanized

EMIT Fully mechanized

ELISA Partly mechanized

4-11

4-11

Partly mechanized

5

ELISA

Partly mechanized

ELISA

ELISA

ELISA

Partly mechanized 5-10

Partly mechanized 11

$6-22$

34

47

48,49

45

45

50

50

50

51

34

ELISA Partly mechanized 5-16 45

mechanized analytical systems, especially with the EMIT, is a basic requirement for the attainment of adequate precision $(62,92)$.

\section{Inaccuracy}

The inaccuracy of enzyme immunoassays is usually examined by comparison of the results with those obtained by other preferably non-immunological procedures, such as gas-liquid chromatography, and by recovery experiments. For many commercial enzyme immunoassays extensive studies in this field have already been published. The results of the EMIT for the determination of theophylline, various antiepileptic drugs and lidocaine were mainly in good agreement with those obtained by uv-spectrophotometry $(44,52-56)$, high-pressure liquid chromatography $(53,54,57-61$, 79) or gas-liquid chromatography (47-49, 56, 62-74, $79)$. In one study, however, highly significant differences between the serum theophylline concentrations determined by EMIT and high-pressure liquid chromatography were observed (80). An adequate correlation was found between radioimmunoassays and EMIT for the measurement of methotrexate (46) and thyroxine (50, 75-77) and heterogeneous enzyme immunoassays for the determination of triiodothyronine $(32,45)$, thyroxine $(32$, $50,78)$, thyrotropin $(35,45,179)$, insulin $(34,114,180)$, total oestrogens $(113), \mathrm{HB}_{\mathrm{s}}$-antigen $(81,82)$ and higher concentrations of antibodies against $\mathrm{HB}_{\mathrm{s}}$-antigen (83). The comparison of enzyme immunoassays (EMIT, ENZYMUN) and various radioimmunoassays for the determination of digoxin with the radioimmunoassay 
Tab. 4. Correlation of various radio- and enzyme immunoassay kits with the Schwarz/Mann digoxin kit $\left({ }^{125} \mathrm{I}\right)$.

\begin{tabular}{llll}
\hline Kit & $\begin{array}{l}\text { Correla- } \\
\text { tion } \\
\text { coeffi- } \\
\text { cient }\end{array}$ & $\begin{array}{l}\text { Regression } \\
\text { constants*) }\end{array}$ & n \\
& r & a & b \\
\hline
\end{tabular}

Radioimmunoassay**)

\begin{tabular}{llllr} 
Amersham & 0.93 & -0.16 & 1.12 & 56 \\
Beckman & 0.94 & -0.08 & 0.94 & 80 \\
Wellcome & 0.88 & -0.13 & 0.96 & 69 \\
& & & & \\
Enzyme immunoassay & & & & \\
EMIT & 0.90 & -0.06 & 1.01 & 130 \\
ENZYMUN & 0.91 & -0.13 & 1.09 & 91 \\
\hline
\end{tabular}

*) Regression constants for the equation $y=a+b x$

**) 125 I-labelled digoxin derivatives were used as tracer in all the radioimmunoassay kits.

Ref. $(84,165)$

of Schwarz/Mann yielded comparable coefficients of correlation and regression constants (tab. 4).

In about $2-3 \%$ of the specimens tested for digoxin reproducible deviations of more than $30 \%$ were found between the results of enzyme- and radioimmunoassays (84). The cause of these discrepancies is not known. A few authors (85) have reported an unsatisfactory correlation between enzyme- and radioimmunoassays for the determination of digoxin, but most authors have reported a satisfactory correlation $(84,86-91,165)$.

The results of the semiquantitative EMIT for the detection of drug abuse in general agreed sufficiently with those obtained by thin-layer chromatography (92-97), gas-liquid chromatography (92) and a gas-chromatographic-mass-spectrometric method (98). The efficiency for the detection of barbiturates, amphetamine and various opiates ranged from $75-98 \%(92,93,95-98)$.

\section{Interferences}

Enzyme immunoassays may be subject to interferences due to distrubances of the enzymic or immunological reaction.

Endogenous enzymes with similar biological effects to the enzyme used as label, or other factors which directly influence the enzymic reaction, may lead to wrong results.

Thus lysozyme, which is used in the EMIT for the detection of drug abuse, is inhibited by high salt concentrations in urine, various substances like heparin, leucine, phenylalanine and cationic detergents, and by $\mathrm{pH}$-values outside of the range $(5.5-8.0)$ recommended by the manufacturer, all of which can cause false negative results $(99,100,172)$. Conversely, false positive results can be found with this assay, due to an excretion of endogenous lysozyme (101). Most of these interferences can be avoided by extraction of the specimen with an appro- priate organic solvent and subsequent determination of the drug in the reconstituted extract $(96,97,172)$.

Horse radish peroxidase, an enzyme frequently used as label in heterogeneous enzyme immunoassays, is prone to inactivation by preservatives and other oxidative and reducing agents (171). Therefore, several authors prefer the use of alkaline phosphatase, especially for competitive ELISA type assays (171).

With the ELISA-technique, interferences by light absorbing substances, such as hemoglobin, bilirubin or turbidities or by endogenous enzymes or enzyme inhibitors are reduced, if the activity of the bound enżyme conjugate is measured. However, the washing-steps required with this technique may theoretically influence the imprecision of these assays considerably.

So far, in most of the homogeneous enzyme immunoassays for quantitative determinations in serum, only a few cases of interference caused by the factors mentioned have been observed. An essential reason for this appears to be the high, about 60 fold, dilution of the serum sample in the reaction medium. Somewhat less favourable conditions are only found with the EMIT for the determination of digoxin (102) or thyroxine $(28,103)$. In order to achieve a sufficient detectability with these procedure, the sample is diluted in the reaction medium only 10 and 20 fold respectively. According to the manufacturer of these assays the serum has to be pretreated with $0.5 \mathrm{~mol} / 1 \mathrm{NaOH}$ in order to avoid interferences from certain serum proteins, such as lactate or malate dehydrogenase.

Furthermore interferences can be caused by an unspecific binding of the conjugate to the solid phase, or by certain plasma proteins or transport proteins, which compete with the antibody.

Cross-reactions with other compounds occur if the antibody lacks specificity. According to our experience, however, the antibodies of most commercial assays for quantitative determinations show a relatively high specificity $(44,46,50,62,84)$.

The specificity of the EMIT and heterogeneous enzyme immunoassays (ENZYMUN) for the determination of digoxin corresponds to that of the radioimmunoassay of Schwarz/Mann (tab. 5). Cross-reactions are observed with structurally closely related compounds, such as digitoxin, and various digoxin metabolites, such as digoxigenin, digoxigenin-bis- and digoxigenin-monodigitoxoside. Canrenone and canrenoate, the major metabolites of spironolactone, apparently do not cause significant interference $(84,89,104,105)$.

In contrast to the enzyme immunoassays for quantitative determinations, most of the semiquantitative EMolT tests for the detection of drugs in urine show a distinctly lower specificity $(92,93)$. Because of possible interferences in these assays, all positive results must be confirmed by a non-immunological method. For clinical toxicological routine determinations it has proved useful 
Tab. 5. Cross-reactivity of digoxin metabolites and various cardiac glycosides*) in enzyme immunoassays (EMIT, ENZYMUN) and a radioimmunoassay (Digoxin Kit (125I), Schwarz/Mann) for determination of digoxin.

\begin{tabular}{llcl}
\hline Compound & $\begin{array}{l}\text { EMIT } \\
\text { nmol/1**) }\end{array}$ & $\begin{array}{l}\text { ENZYMUN } \\
\text { nmol/1 }\end{array}$ & $\begin{array}{l}\text { RIA } \\
\text { nmol/1 }\end{array}$ \\
\hline $\begin{array}{l}\text { Digoxin } \\
\text { Digoxigenin-bis- } \\
\text { digitoxoside }\end{array}$ & $1.28(100 \%)$ & $1.28(100 \%)$ & $1.28(100 \%)$ \\
$\begin{array}{l}\text { Digoxigenin- } \\
\text { mono- }\end{array}$ & $1.92(67 \%)$ & $1.71(75 \%)$ & $1.37(93 \%)$ \\
digitoxoside & $2.13(60 \%)$ & $1.74(74 \%)$ \\
$\begin{array}{l}\text { Digoxigenin } \\
\text { Lanatoside C }\end{array}$ & $1.92(67 \%)$ & $3.20(40 \%)$ & $2.56(50 \%)$ \\
$\begin{array}{l}\text { Digitoxin } \\
\text { Ouabain }\end{array}$ & $13.07(10 \%)$ & $12.42(10 \%)$ & $11.90(11 \%)$ \\
\hline
\end{tabular}

*) Substances were added to drug-free human serum.

**) Concentration resulting in an absorbance or in counts per minute equivalent to $1.28 \mathrm{nmol} / 1$ digoxin. The ratio of $1.28 \mathrm{nmol} / 1$ digoxin/corresponding concentration of the compound tested is given in parenthesis.

Ref. $(84,165)$

to perform a thin-layer chromatographic screening test and to use the EMIT as a confirmation analysis $(92,96$, 97).

In the detection of barbiturates it was shown that the predictive value for a positive result and the diagnostic specificity were much higher when thin-layer chromatography and EMIT were used sequentially, than when the tests were performed singly or in parallel (106).

\section{Detection limits}

The detectability of the enzyme immunoassay depends on certain variables, such as the assay conditions, the enzyme-substrate combination, the antigen and especially the affinity of the antibody for the antigen $(22,171)$. Larger differences in the affinity of the antibody for labeled and unlabeled antigen have an unfavourable effect on the detectability of the assay (107).

Nowadays the limits of detection for the enzyme immunoassay, based on various parametèrs, are already equal to those of the radioimmunoassay. In general the detection limits of the radioimmunoassays range from 1$500 \mathrm{pmol} / 1$ or $0.2-50 \mathrm{fmol} / \mathrm{tube}$ (22). Comparable detection limits were observed for example with heterogeneous enzyme immunoassays for the determination of $\mathrm{HB}_{\mathrm{s}}$-antigen and insulin (tab. 6). A recently described enżyme immunoassay is capable of detecting even 1 attomol of ornithine- $\delta$-aminotransferase $(108,109)$.

Other asssays, for instance for the determination of $\alpha_{1}$-fetoprotein $(51,111)$ or digoxin show a detectability which is more than five times lower than that of the corresponding radioimmunoassays (22). Except for the EMIT digoxin assay, the remaining homogeneous enzyme immunoassays for the determination of drugs show a comparatively low detectability (tab. 6), which, however,
Tab. 6. Detection limits with various enzyme immunoassay kits.

\begin{tabular}{lll}
\hline Antigen/hapten & $\begin{array}{l}\text { Detection limit*) } \\
\text { (pmol/1) }\end{array}$ & Ref. \\
\hline
\end{tabular}

1. Heterogeneous enzyme

$\mathrm{HB}_{\mathrm{s}}$-antigen

Carcinoembryonic an tigen

$0.9-1.6$

2.5

3.3

30.0

Thyrotropin**)

Insulin

$\alpha_{1}$-Fetoprotein

Oestriol

Digoxin

35.0

42.9

$2.0 \times 10^{2}$

$4.0 \times 10^{2}$

$3.9 \times 10^{4}$

(22)

(112)

(110)

(179)

$(34,114)$

(51)

Thyroxine

(113)

2. Homogeneous enzyme immunoassays (EMIT)

Digoxin

Thyroxine

Propranolol**)

Methotrexate

Phencyclidine

Methadone

Morphine

Diazepam

Oxazepam

Quinidine.

Propoxyphen

$\mathrm{N}$-Acetylprocainamide

Secobarbital

Tobramycin**)

Gentamicin

Theopyhlline

Amphetamine

Benzoyl Ecgonine

Phenytoin

Procainamide

Lidocaine

Carbamazepine

Primidone

Secobarbital**)

Valproic acid**)

Phenobarbital

Ethosuximide

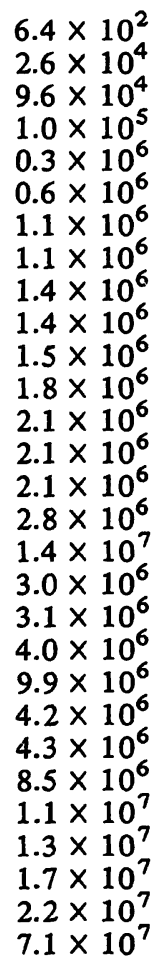

*) Where data on the detection limit are not available, the concentration of the lowest calibrator different from zero is quoted instead of the detection limit, which actually may be lower.

**) Reagents are not yet commercially available.

is sufficient for the detection of diagnostically relevant serum or urine concentrations of these substances. The advantage of working at a lower detectability is that only very short periods of 30-150 seconds are necessary for the measurement of the enzyme activities. Accordingly in a series of 20 samples the time needed for a determination (incubation periods included) is about 3-6 minutes by EMIT and 10-70 minutes by ELISA type assays (tab. 7).

The detectability of homogeneous enzyme immunoassays can be increased, if the reaction of the enzymedrug conjugate with the antibody is stopped after a short time by saturating the antibody with a larger quantity of unlabeled drug (126). 
Tab. 7. Time required per determination with various enzyme immunoassays.

\begin{tabular}{|c|c|c|c|}
\hline Compound & Assay principle & $\begin{array}{l}\text { Time } \\
\text { required } \\
\text { (min/ } \\
\text { deter- } \\
\text { mina- } \\
\text { tion*) }\end{array}$ & Ref. \\
\hline $\begin{array}{l}\text { Phenobarbital } \\
\text { Phenytoin } \\
\text { Carbamazepine }\end{array}$ & & & \\
\hline $\begin{array}{l}\text { Primidone } \\
\text { Ethosuximide } \\
\text { Theophylline }\end{array}$ & EMIT $^{* *}$ ) & 3 & $(44,45,62)$ \\
\hline Methotrexate & EMIT***) & 4 & (46) \\
\hline Digoxin & $\begin{array}{l}\text { EMIT***) } \\
\text { ELISA***) }\end{array}$ & $\begin{array}{l}6 \\
9\end{array}$ & $\begin{array}{l}(84) \\
(84)\end{array}$ \\
\hline Thyroxine & $\begin{array}{l}\text { EMIT***) } \\
\text { ELISA }^{* * *} \text { ) }\end{array}$ & $\begin{array}{r}3 \\
13\end{array}$ & $\begin{array}{l}(50) \\
(50)\end{array}$ \\
\hline Insulin & ELISA***) & 68 & (45) \\
\hline
\end{tabular}

*) duplicate determinations, incubation period included

**) number of different patient samples per series $\mathrm{n}=\mathbf{3 0}$

$* * *) \mathrm{n}=20$

\section{Mechanization}

For routine application, the mechanization of enzyme immunoassays appears to be of great importance (127).

The homogeneous enzyme immunoassays have very favorable properties for mechanization; all reactants are present in one reaction medium, the time for the measurement of the enzyme activities is short and longer incubation periods are avoided.

So far the analytical systems listed in table 8 have proved useful for the mechanization of the EMIT. Photometers equipped with thermally regulated flow-cells in combination with suitable dispensers and dilutors, and centrifugal analyzers, are mainly used in partly mechanized procedures. The use of fully mechanized analytical systems for the determination of enzyme activities has to be considered as a further step towards rationalization of these assays. With an Eppendorf system ACP 5040, for example, about 250 patient samples can be analyzed by one technical assistant per day, and the direct costs for technician time and reagents

Tab. 8. Mechanized procedures for the performance of EMIT assays.

1. Partly mechanized procedures

Gilford $300 \mathrm{~N}$

Gilford Stasar III

Beckman 24/25

Beckman Trace III

Eppendorf 5085

Eppendorf 5090

Shimadzu UV-200

Miniature Centrifugal Analyzer

IL Multistat III MCA

Centrifichem

Gemsaec

LKB Reaction Rate Analyzer

Labtronic ES 25

Perkin-Elmer 124 D

Kem-o-Mat

Aminco Rotochem II

ABA-100

2. Fully mechanized procedures

Eppendorf Analyzer 5010

Eppendorf System ACP 5040

Gilford 3500

ACA Du Pont

KDA American Monitor

Vitatron AKES

LKB Auto Chemist

KA-150 Perkin Elmer

SMA $12 / 60$
Phenytoin, phenobarbital, primidone $(63,65,66)$, opiates $(101)$

Digoxin (86), theophylline (173)

Phenytoin, phenobarbital (56), primidone (69), digoxin (87), carbamażẹpine, ethosuximide (67)

Theophylline, phenobarbital (128)

Barbiturates, opiates, amphetamine, methadone, benzoyl ecgonine, oxazepam (92)

Digoxin (84)

Opiates (98)

Phenobarbital, phenytoin $(129,164)$, digoxin $(130)$

Theophylline, thyroxine $(131,132)$, phenobarbital, phenytoin $(131,132)$, opiates $(133)$

Phenytoin, phenobarbital, primidone, carbamazepine, digoxin $(90,134-136)$, theophylline (137)

Barbiturates, opiates, amphetamine, methadone $(138)$, pheny toin $(79,139,140)$, phenobarbital

$(79,140)$, theophylline, primidone, carbamazepine, ethosuximide (79)

Phenobarbital (141)

Digoxin (45)

Phenytoin (142)

Thyroxine (76)

Phenytoin (64), phenobarbital (150), theophylline (151)

Barbiturates, opiates, amphetamine, methadone, benzoyl ecgonine (143), phenytoin, phenobarbital $(144,146)$, primidone, ethosuximide, carbamazepine (146), thyroxine $(50,77)$, digoxin $(136)$, theophylline (53), cortisol (145)

Phenytoin, phenobarbital (62), primidone, carbamazepine, ethosuximide, lidocaine (45), theophylline (44), methotriexate (46)

Phenobarbital (45), theophylline (173)

Phenytoin, phenobarbital, primidone, ethosuximide, carbamazepine (146), lidocaine (47)

Phenytoin, phenobarbital, carbamazepine, primidone, ethosuximide $(147-149,166)$

Opiates, amphetamine, methadone, barbiturate (152)

Phenytoin, phenobarbital, primidone, carbamazepine (153)

Thyroxine (75)

Phenytoin, phenobarbital, primidone (74), theophylline (52)

Thyroxine (154) 
Tab. 9. Various analy tical systems used for heterogeneous enzyme immunoassays.

\begin{tabular}{ll}
\hline Eppendorf 5090 & Titertek-Multiskan \\
Eppendorf 5091-A & LKB 2074 \\
Gilford EIA-PR 50 & Zeiss PRP 8 \\
Abbott Quantum I & Riele PMC Automatik
\end{tabular}

are about $50 \%$ lower than with the original procedure (173).

For the rapid analysis of single emergency requests, the ACA from DuPont apppears to be very suitable. With this analytical system a calibration curve need not be prepared for every run, providing the same lot of EMIT tests is used $(127,166)$. An emergency determination of phenytoin, for example, takes about 15 minutes (166). So far, however, only EMIT tests for the determination of various antiepileptic drugs are available for this system.

Because of the long incubation periods, and the washingand separation steps, it is more difficult to mechanize the ELISA-technique than the EMIT.

Certain steps, however, such as the washing procedure, the dispensation of the reagents and the photometrical measurement have already been mechanized (127). Various analytical systems, which can be used to partly mechanize heterogeneous enzyme immunoassays, are listed in table 9. The newly developed system EIA-PR 50 from Gilford shows a relatively high degree of mechanization and a good practicability. Antibody coated cuvettes for this system are, however, are not yet commercially available.

In our experience it was possible to coat the cuvettes supplied with this system with an antibody directed against thyroxine (45). Subsequently the coated cuvettes were used in an enzyme immunoassay for the determination of this hormone (45).

\section{Evaluation of the Results}

Computers are used increasingly for the evaluation of the results from enzyme immunoassays. The manual procedures are lengthy, and sometimes less dependable.

Various methods may be used for curve-fitting (155162). These procedures are based either on certain models or only on the data of the calibration points (tab. 10). The most suitable method must first be ascertained for each enzyme immunoassay.

A weighted linear and non-linear regression after logit$\log$ transformation $(156,158)$ and an empirical spline interpolation (161) have proved to be useful for the evaluation of the results obtained by the EMIT.

There are only limited data for the computer analysis of results from the ELISA-technique. With the ENZYMUN digoxin assay, for example, a computer program based on the parabolic regression has been used (162).
Tab. 10. Curve-fitting methods for enzyme immunoassay.

1. Model-based methods

1.1 Parabolic regression (162)

1.2 Linear regression after logit-log transformation (156)

1.3 Weighted linear regression after logit-log transformation (156)

1.4 Weighted non-linear regression after logit-log transformation (158)

2. Data-based methods

2.1 Manual curve-fit

2.2 Polygonal interpolation (156)

2.3 Empiric spline-interpolation (161)

2.4 Cubic spline-interpolation (156)

2.5 Spline approximation (159)

On principle all calibration curves calculated by a computer should be checked visually.

A definitive recommendation of certain curve-fitting methods for enzyme immunoassays cannot be given at present, as extensive comparative studies with these procedures are needed.

\section{Conclusion}

Most of the currently commercially available enzyme immunoassays for the determination of haptens, such as various drugs $(44,46,49,62,79,84,92,93)$ and

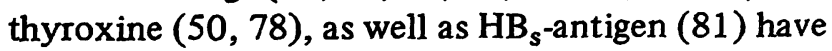
already reached a stage of development, in which they appear to be suitable for routine application in appropriate centers, such as the central laboratories of larger hospitals. Despite their ease of operation, however, these assays require certain experience on the part of the analyst, who must take account of a large number of possible sources of interference.

The development of the enzyme immunoassay is currently still in a state of flux. It has to be expected that the detectability, precision, specificity and practicability of these assays will be further improved. Possible sources of improvement lie in a better standardization of the reagents and methods, the search for more effective marker enzymes and the evaluation of alternative procedures for the determination of enzyme activities, such as fluorimetry, luminescence photometry and thermometry. A far-reaching mechanization of the enzyme immunoassays appears to be essential. According to existing experience, the improvement of the reliability and practicability of these assays by mechanization is likely to be far greater than the beneficial effects of mechanization on the commonly used clinical chemical routine procedures. Furthermore the costs for reagents and technician time can be considerably reduced $(44-46,62,129,150,163,164,173)$, if a suitable mechanization is chosen.

-Recently enzyme immunoassays gained a relatively great expansion in the area of therapeutic drug monitoring, where procedures of a comparable simplicity and specificity were not hitherto available. Using enzyme 
immunoassays it has now become relatively easy to introduce the monitoring of the serum concentrations of various drugs, and the detection of drugs in urine into the routine program of clinical chemical laboratories. According to our experience there is an increasing demand for such determinations. It has to be assumed that this trend will continue.

\section{References}

1. Yalow, R. S. \& Berson, S. A. (1959), Nature 184, 16481649.

2. Engvall, E. \& Perlmann, P. (1971), Immunochemistry 8 , 871-874.

3. Van Weemen, B. K. \& Schuurs, A. H. W. M. (1971), FEBSLett. 15, 232-235.

4. Rubenstein, K. E., Schneider, R. S. \& Ullmann, E. F. (1972), Biochem. Biophys. Res. Commun. 47, 846-851.

5. Carrico, R. J., Christner, J. E., Boguslaski, R. C. \& Yeung, K. K. (1976), Anal. Biochem. 72, 271-282.

6. Schroeder, H. R., Carrico, R. J., Boguslaski, R. C. \& Christner, J. E. (1976), Anal. Biochem. 72, 283-292.

7. Burd, J. F., Carrico, R. J., Fettner, M. C., Buckler, R. T. Johnson, R. D., Boguslaski, R. C. \& Christner, J. E. (1977), Anal. Biochem. 77, 56-67.

8. Burd, J. F., Wong, R. C., Feeney, J. E., Carrico, R. J. \& Boguslaski, R. C. (1977), Clin. Chem. 23, 1402-1408.

9. Wong, R. C., Burd, J. F., Carrico, R. J., Buckler, R. T. Thoma, J. \& Boguslaski, R. C. (1979), Clin. Chem. 25, 686-691.

10. Dandliker, W. B., Schapiro, M. C., Meduski, J. W., Alonso, R., Feigen, G. A. \& Hamrick, J. R. (1964), Immunochemistry $1,165-191$.

11. Ullman, E. F., Schwarzberg, M. \& Rubenstein, K. E. (1976), J. Biol. Chem. 251, 4172-4178.

12. Sedlacek, H. H., Mück, K. F., Rehkopf, R., Baudner, S. \& Seiler, F. R. (1979), J. Immunol. Meth. 26, 11-24.

13. Soini, E. \& Hemmilä, I. (1979), Clin. Chem. 25, 353-361.

14. Pratt, J. J., Woldring, M. G. \& Villerius, L. (1978), J. Immunol. Meth. 21, 179-184.

15. Olsson, T., Brunius, G., Carlsson, H. E. \& Thore, A. (1979), J. Immunol. Meth. 25, 127-135.

16. Leute, R. K., Ullman, E. F. \& Goldstein, A. (1972), J. Am. Med. Assoc. 221, 1231-1234.

17. Haimovich, J. \& Sela, M. (1969), Science 164, 1279- 1280.

18. Landon, J., Crockall, J. \& McGregor, A. (1975), in: Steroid Immunoassay (Cameron, E. H. D., Hillier, S. G. \& Griffiths, K., eds.), Alpha Omega Publishing Ltd. Cardiff, 183-188.

19. Voller, A., Bidwell, D. E. \& Bartlett, A. (1976), Bull. WHO 53, 55-65.

20. Scharpé, S. L., Cooreman, W. M., Blomme, W. J. \& Laekeman, G. M. (1976), Clin. Chem. 22, 733-738.

21. Wisdom, G. B. (1976), Clin. Chem. 22, 1243-1255.

22. Schuurs, A. H. W. M. \& van Weemen, B. K. (1977), Clin. Chim. Acta $81,1-40$.

23. Haeckel, R. \& Oellerich, M. (1977), Lab. Med. 1, 121-131.

24. Dellamonica, C., Baltassat, P. \& Collombel, C. (1977), Lyon Pharmacentique 28, 289-303.

25. Jarvis, R. F. (1979), Antibiotics Chemother. 26, 105-117.

26. Schuurs, A. H. W. M. \& van Weemen, B. K. (1979), Dt. Ges. f. Klin. Chemie e. V. - Mitteilungen 1, 22-31.

27. Rowley, G., Rubenstein, K., Huisjen, J. \& Ullman, E. (1975), J. Biol. Chem. 250, 3759-3766

28. Ullman, E. F., Blakemore, J., Leute, R. K., Eimstad, W. \& Jaklitsch, A. (1975), Clin. Chem. 21, 1011.

29. Morita, T. N. \& Woodburne, M. J. (1978), Infection and Immunity $21,666-668$

30. Gibbons, I., Skold, C., Rowley, G. L. \& Ullman, E. F. (1979), Clin. Chem. 25, 1078.

31. Kleinhammer, G., Lenz, H., Linke, R. \& Gruber, W. (1976), $2^{\text {nd }}$ European congress on clinical chemistry, Prague, Abstracts.
Enzyme immunoassays are also increasingly used for the determination of other parameters, such as various hormones, $\mathrm{HB}_{\mathrm{s}}$-antigen and antibodies. Further suitable candidates for enzyme immunoassays are enzymes, lipopróteins and bile acids $(167-170,181)$. We believe that in the future enzyme immunoassays will gain increasing importance in clinical chemistry.

32. Kleinhammer, G., Lenz, H., Linke, R. \& Staehler, F. (1978), in: Enzymimmunoassay, Grundlagen und praktische Anwendung (Vogt, W., ed.), G. Thieme Verlag.Stuttgart, $42-51$.

33. Zettner, A. \& Duly, P. E. (1974), Clin. Chem. 20, 5-14.

34. Kleinhammer, G., Lenz, H., Linke, R. \& Gruber, W. (1976), Z. Anal. Chem. 279, 145.

35. Staehler, F., Linke, R., Glatz, Ch., Albert, W.H. W. \& Tanswell, P. (1979), Kongreß der Deutschen Gesellschaft für Laboratoriumsmedizin, Berlin, Abstracts, p. 58.

36. Pratt, J. J. \& Woldring, M. G. (1976), Clin. Chim. Acta 68, 87-90.

37. Guesdon, J. L., Thierry, R. \& Avraméas, S. (1978), J. Allergy Clin. Immunol. 61, 23-27.

38. Velan, B. \& Halmann, M. (1978), Immunochemistry 15 , $331-333$

39. Boitieux, J. L., Desmet, G. \& Thomas, D. (1979), Clin. Chem. 25, 318-321.

40. Borrebaeck, C., Börjeson, J. \& Mattiasson, B. (1978), Clin. Chim. Acta 86, 267-278.

41. Hamaguchi, Y., Kato, K., Ishikawa, E., Kobayashi, K. \& Katunuma, N. (1976), FEBS-Lett. 69, 11-14.

42. Kitagawa, T. \& Aikawa, T. (1976), J. Biochem. 79, $233-$ 236.

43. Waart, M. v. d. \& Schuurs, A. H. W. M. (1976), Ż. Anal. Chem. 279, 142.

44. Oellerich, M., Sybrecht, G. W. \& Haeckel, R. (1979), J. Clin. Chem. Clin. Biochem. 17, 299-302.

45. Oellerich, M., unpublished data.

46. Oellerich, M., Engelhardt, P., Schaadt, M. \& Diehl, V. (1980), J. Clin. Chem. Clin. Biochem. 18, 169-174.

47. Lehane, D. P., Wissert, P. J., Menyharth, P., Levy, A. L. \& Kukucka, M. (1979), Clin. Chem. 25, 614-616.

48. Pape, B. E., Whiting, R., Parker, K. M. \& Mitra, R. (1978), Clin. Chem. 24, 2020-2022.

49. Walberg, C. B. (1978), J. Anal. Toxicol. 2, 121-123.

50. Oellerich, M., Haindl, H. \& Haeckel, R. (1979), J. Clin. Chem. Clin. Biochem. 17, 483-488.

51. Albert, W. H. W., Staehler, F. \& Gruber, W. (1978), Lab. Med. 2, 31-35.

52. Castro, A., Ibanez, J., Voight, W., Nato, T. \& Malkus, H. (1978), Clin. Chem. 24, 944-946.

53. Tieber, V. L., Weidner, N., Smith, C. H., Kessler, G., McDonald, I. H., Ladenson, J. M. \& Dietzler, D. N. (1978), Clin. Chem. 24, 1056.

54. Chamberlain, R. T. \& Sun, L. (1978), Clin. Chem. 24, 1057.

55. Henry, V., Deutsch, J. \& Lum, G. (1978), Clin. Chem. 24, 514.

56. Spiehler, V., Sun, L., Miyada, D. S., Sarandis, S. G., Walwick, E. R., Klein, M. W., Jordan, D. B. \& Jessen, B. (1976), Clin. Chem. 22, 749-753.

57. Ryder, K. W., Oei, T. O., Glick, M. R., Jimerson, J. G. \& Kellog, T. L. (1978), Clin. Chem. 24, 1057.

58. Eppel, M. L., Oliver, J. S. \& Smith, H. (1978), Analyst 103, 1061-1065.

59. Kôup, J. R. \& Brödsky, B. (1978), Amer. Rèv. Respiratory Dis. $117,1135-1138$

60. Mihaly, G. W., Phillips, J. A., Louis; W. J. \& Vajda, F. J. (1978), Clin. Chem. 23, 2283-2287.

61. Dellamonica, C., Borg, C., Baltassat, P. \& Lahet, C. (1978), Clin. Chim. Acta 86, 1-5. 
62. Oellerich, M., Külpmann, W. R., Haeckel, R. \& Heyer, R. (1977), J. Clin. Chem. Clin. Biochem. 15, 353-358.

63. Legaz, M. \& Raisys, V. A. (1976), Clin. Biochem. 9, 35-38.

64. Finley, P. R., Williams, R. J. \& Byers, J. M. (1976), Clin. Chem. 22, 911-914.

65. Pippenger, Ch. E., Bastiani, R. J. \& Schneider, R. S. (1975), in: Clinical Pharmacology of Antiepileptic Drugs (Schneider, H. \& Janz, D. eds.), Springer, Berlin, 331335.

66. Booker, H. E. \& Darcey, B. A. (1975), Clin. Chem. 21, 1766-1768.

67. Sun, L. \& Szafir, 1. (1977), Clin. Chem. 23, 1753-1756.

68. Schmidt, D. (1976), J. Neurol. 213, 41-46.

69. Sun, L. \& Walwick, R. E. (1976), Clin. Chem. 22, 901902.

70. Watanabe, S., Kuyama, C., Yokoyama, S., Kubo, S. \& Iwai, H. (1977), Kawasaki Med. J. 3, 59-66.

71. Stanley, P. E. \& Peikert, M. R. (1978), Epilepsia 19, 265-272.

72. Pilgerstorfer, H. W., Ruprechtsberger, E., Richens, A. \& Hebdige, S. J. (1978), Wien Med. Wochenschr. 128, 356360.

73. Nandedkar, A. K., Kutt, H. \& Fairclough, G. F. (1978), Clin. Toxicol. 12,483-494.

74. McClean, S. W., Young, D. S. \& Yonekawa, W. (1977), Clin. Chem. 23, 116-118.

75. Galen, R. S. \& Forman, D. (1977), Clin. Chem. 23, 119121.

76. Riesen, W. F., Muacevic, B. \& Jaggi, M. (1978), J. Clin. Chem. Clin. Biochem. 16, 387-389.

77. Finley, P. R. \& Williams, R. J. (1978), Clin. Chem. 24, 165-167.

78. Borner, K., Colombo, J. P., Bachmann, C., Haeckel, R., Oellerich, M., Westerink, D., Fischer, M., Wimmer, P., Vogt, W., Tausch, A., Knedel, M., Minder, W., Blum, J. \& Portenhauser, R. (1979), J. Clin. Chem. Clin. Biochem. 17, 471-481.

79. Urquhart, N., Godolphin, W. \& Campbell, D. J. (1979), Clin. Chem. 25, 785-787.

80. Sheen, A. E., Sly, R. M., Hite, S., Giblin, V. R. \& Hebert, M. (1979), Ann. Allergy 42, 77-79.

81. Wolters, G., Kuijpers, L., Kacaki, J. \& Schuurs, A. (1976), J. Clin. Pathol. 29, 873-879.

82. Lange, W., Köhler, H., Apodaca, J., Ott, A. \& Sucker, U. (1977), Dtsch. med. Wochenschr. 102, 1581-1585.

83. Lange, W. \& Köhler, H. (1978), Dtsch. med. Wochenschr. $103,1873-1877$.

84. Oellerich, M., Haindl, H. \& Haeckel, R. (1978), Internist $19,188-190$.

85. Müller, M., Bräuer, M., Reinhardt, M. \& Förstẹr, G. (1976), Ärztl. Lab. 22, 399-4:02.

86. Rosenthal, A. F., Vargas, M. G. \& Klass, C. S. (1976), Clin. Chem. 22, 1899-1902.

87. Sun, L. \& Spiehler, V. (1976), Clin. Chem. 22, 20292031.

88. Drost, R. H., Plomp, Th. A., Teunissen, A. J., Maas, A. H. J. \& Maes, R. A. A. (1977), Clin. Chim. Acta 79, 557568.

89. Borner, K. \& Rietbrock, N. (1978), J. Clin. Chem. Clin. Biochem. 16, 335-342.

90. Vogt, W., Tausch, A., Jacob, K. \& Knedel, M. (1977), J. Clin. Chem. Clin. Biochem. 15, 194-195.

91. Eriksen, P. B. \& Andersen, O. (1978), Clin. Chem. 25, 169-171.

92. Oéllerich, M., Külpmann, W. R. \& Haeckel, R. (1977), J. Clin. Chem. Clin. Biochem. 15, 275-283.

93. Mulé, S. J., Bastos, M. L. \& Jukofsky, D. (1974), Clin. Chem. 20, 243-248.

94. Molntyre, J. A., Armandi, A. E., Risen, L. P., Ling, W. \& Haberfelde, G. C. (1975), Clin. Chem. 21, 109-112.

95. Cavanagh, K., Draisey, T. F. \& Thibert, R. J. (1978), Clin. Biochem. 11, 210-213.

96. Oellerich, M. \& Haeckel, R. (1979), Lab. Med. 3, 65-70.

97. Oellerich, M. (1979), in: Praktische Anwendung des Enzymimmunoassays in der Klinischen Chemie und Serologie (Vogt, W., ed.), G. Thieme Verlag, Stuttgart, 66-75.
98. Slooten, E. P. J. v. d. \& Helm, H. J. v. d. (1976), Clin Chem. 22, 1110-1111.

99. Kim, H. J. \& Cerceo, E. (1976), Clin. Chem. 22, 19351936.

100. Andersen, O. \& Eriksen, P. B. (1977), Clin. Chem. 23, $751-753$.

101. Schneider, R. S., Lindquist, P., Wong, E. T., Rubenstein, K. E. \& Ullman, E. F. (1973), Clin. Chem. 19, 821-825.

102. Chang, J. J., Crowl, C. P. \& Schneider, R. S. (1975), Clin. Chem. 21, 967.

103. Jacklitsch, A. P., Schneider, R. S., Johannes, R. J., Lavine, J. E. \& Rosenberg, G. L. (1976), Clin. Chem. 22, 1185.

104. Munz, E., Kessler, A., Koller, P. U. \& Busch, E. W. (1979), Lab. Med. 3, 71-76.

105. Lichey, J., Rietbrock, N. \& Borner, K. (1979), Internat. J. Clin. Pharmacol. Biopharm. 17, 61-63.

106. Oellerich, M. \& Haeckel, R. (1978), Med. Welt 29, 866 872.

107. Pratt, J. J. (1978), Clin. Chem. 24, 1869-1890.

108. Kato, K., Hamaguchi, Y., Okawa, S., Ishikawa, E., Kobayashi, K. \& Katunuma, N. (1977), Lancet $I, 40$.

109. Ishikawa, E. \& Kato, K. (1978), Scand. J. Immunol. 8 , 43-55.

110. Fortier, R. \& Twomey, S. (1978), Clin. Chem. 24, 1017.

111. Masseyeff, R. (1978), Scand. J. Immunol. 8, 83-90.

112. CEA-EIA, Anti-carcinoembryonic Antigen (Goat): Peroxidase (Horseradish) Conjugate. Abbott Diagnostics Division, Langen, Germany (1979), p. 7.

113. Bosch, A. M. G., Dijkhuizen, D. M., Schuurs, A. H. W. M \& van Weemen, B. K. (1978), Clin. Chim. Acta 89, 59-70.

114. Yoshioka, M., Taniguchi, H., Kawaguchi, A., Kobayashi, T., Murakami, K., Seki, M., Tsutou, A., Tamagawa, M., Minoda, H. \& Baba, S. (1979), Clin. Chem. 25, 35-38.

115. Collins, C., Hu, M., Crowl, C., Kabakoff, D. S. \& Singh, P. (1979), Clin. Chem. 25, 1093.

116. Izutsu, A., Leung, D., Araps, C., Singh, P., Jaklitsch, A. \& Kabakoff, D. G. (1979), Clin. Chem. 25, 1093.

117. Leung, D., Tsay, Y., Sing, P., Jaklitsch, A. \& Kabakoff, D. S. (1979), Clin. Chem. 25, 1094.

118. Tom, H., Schneider, R. S., Ernst, R., Khan, W., Singh, P. \& Kabakoff, D. (1979), Clin. Chem. 25, 1094.

119. Tom, H., Kabakoff, D. S., Lin, C. J., Singh, P., White, M., Westkamper, P., McReynolds, C. \& de Porceri-Morton, K. (1979), Clin. Chem. 25, 1144.

120. Izutsu, A., Pirio, M. R., Buckley, N., Singh, P., Gushaw, J. B., Miller, J. G. \& Schneider, R. S. (1978), Clin. Chem. $24,1055$.

121. Kabakoff, D. S., Leung, D. \& Singh, P. (1978), Clin. Chem. 24, 1055.

122. Chegwidden, K., Pirio, M. R., Singh, P., Gushaw, J. B., Miller, J. G. \& Schneider, R. S. (1978), Clin. Chem. 24, 1056.

123. Fanciullo, R. A., Huber, N., Izutsu, A., Pirio, M. R., Buckley, N., Singh, P., Gushaw, J. B., Miller, J. G. \& Schneider, R. S. (1978), Clin. Chem. 24, 1056.

124. Wettengel, R., Oellerich, M. \& Schnitker, J. (1979), Praxis und Klinik der Pneumonologie 33, 1125-1133.

125. Antiepileptica, Emit-aed, Syva, Palo Alto, Calif., USA (1978), p. 24

126. Lasky, F. D., Razi, J. A. \& Karmen, A. (1978), Clin. Chem. 24, 1381-1385.

127. Oellerich, M. \& Haeckel, R. (1979), in: Rationalisierung des medizinischen Laboratoriums (Haeckel, R., ed.), GITVerlag, Darmstadt, 188-195.

128. Sun, L., Klein, M. \& Valter, P. (1979), Clin. Chem. 25, 1129

129. Brunk, S. D., Hadjiioannou, T. P., Hadjiioannou, S. J. \& Mälmstadt, H. V. (1976), Clin. Chem. 22, 905-907.

130. Brunk, S. D. \& Malmstadt, H. V. (1977), Clin. Chem. 23, 1054-1056.

131. Tiffany, T. O., Hills, L. P., Thayer, P. C., Frankart, M. \& Jurczyk, C. (1979), Clin. Chem.25, 1094.

132. Hicks, J. M., Josefsohn, M. \& Rucker, H. K. (1979), Clin. Chem. 25, 1095.

133. Tiffany, T. O., Hills, L. P., Huey, E. \& Jurczyk, C. (1979), Clin. Chem. 25, 1094.

134. Haven, M. (1976), Clin. Chem. 22, 2057. 
135. Tausch, A., Vogt, W., Jacob, K. \& Knedel, M. (1977), J. Clin. Chem. Clin. Biochem. 15, 141-142.

136. Scoggin, D., Petrehn, J. \& Besemer, D. (1978), Clin. Chem. $24,1055$.

137. Rosner, G. \& Khayam-Bashi, H. (1979), Clin. Chem. 25, 1130.

138. Broughton, A. \& Ross, D. L. (1975), Clin. Chem. 21, 186189.

139. Wersch, J. v., Löffler, U. \& Kleesiek, K. (1977), J. Clin. Chem. Clin. Biochem. 15, 196.

140. Strasser, B. \& Zinterhofer, L. (1975), Clin. Chem. 21, 946.

141. Belfield, A., Duncan, A. M. \& Reavey, P. C. (1977), Ann. Clin. Biochem. 14, 218-222.

142. Contant, I. \& Byvoet, P. (1977), Clin. Chem. 23, 1794.

143. Syva Corp., Palo Alto, USA (1974), Instructions for EMIT ABA assays.

144. Lente, F. v., Warkentin, D. \& Ohno, T. (1977), Clin. Chem. $23,761-762$.

145. Winfrey, L. J., Johns-Stephens, L. \& Greenwood, H. M. (1979), Clin. Chem. 25, 1151.

146. Hoelting, C. R., Tieber, V. L., Smith, C. H. \& Dietzler, D. N. (1979), Clin. Chem. 25, 1096

147. Nandedkar, A. K. N., Gimblet, G., Kutt, H. \& Fairclough, G. F. (1979), Clin. Chem. 25, 1096.

148. Miesowicz, F. M., Dickinson, J. C., Jain, P. H., Byrd, J. J. \& Humphries, B. A. (1979), Clin. Chem. 25, 1096.

149. Treuting, J. J., Gudat, J. C. \& Wilder, B. J. (1979), Clin. Chem. 25, 1089.

150. Finley, P. R., Williams, R. J., Lichti, D. F. \& Byers, J. M. (1977), Clin. Chem. 23, 738-740.

151. Sedor, F. A., Jacobson, D. L., Holleman, C. \& Cross, R. E. (1978), Clin. Chem. 24, 1057.

152. Pearson, J. R. (1978), Clin. Chem. 24, 1823-1825.

153. Luderer, T. K. J., Schneider, M. \& Rambeck, B. (1977), J. Clin. Chem. Clin. Biochem. 15, 173.

154. Lavin, S. A., McNeil, K. G. \& Greenwood, H. M. (1979), Clin. Chem. 25, 1103.

155. Vogt, W., Popp, B. \& Knedel, M. (1973), Z. Klin. Chem. Klin. Biochem. 11, 438-445.

156. Sandel, P. \& Vogt, W. (1977), GIT Fachz. Lab. 21, 295298.

157. Challand, G. S. (1978), Ann. Clin. Biochem. 15, 123-135.

158. Rodbard, D. \& McClean, S. W. (1977), Clin. Chem. 23, 112-115.

159. Nolte, H., v. z. Mühlen, A. \& Hesch, R. D. (1976), J. Clin. Chem. Clin. Biochem. 14, 253-259.

160. Marschner, I., Erhardt, F. \& Scriba, P. C. (1973), Internat. Atomic Energy Agency, Symposium on radioimmunoassay and related procedures in clinical medicine and research, Istanbul, 111-122.
161. Porth, A. \& Oellerich, M., J. Clin. Chem. Clin. Biochem., in prep.

162. Carl Zeiss, D-7082 Oberkochen, West-Germany (1977), Instructions for the Photometerautomat PRP 8, Anwendung Nr. 3.

163. Kleine, T. O. (1978), Clin. Chim. Acta 82, 193-195.

164. Lasky, F. D., Ahuja, K. K. \& Karmen, A. (1977), Clin. Chem. 23, 1444-1448.

165. Oellerich, M., Haeckel, R. \& Haindl, H. (1978), $X^{\text {th }}$ international congress of clinical chemistry, Mexico, Abstracts, p. 68.

166. Haeckel, R. \& Oellerich, M. (1980), Dt. Ges. f. Klin. Chemie e. V. - Mitteilungen, in press.

167. Landon, J. (1979), Antibiotics Chemother 26, 118-128.

168. Grenner, G. \& Schmidtberger, R. (1979), J. Clin. Chem. Clin. Biochem. 17, 156.

169. Carlier, Y., Bout, D., Fruchart, J.-Ch., Desreumaux, C., Dewailly, P., Sezille, G. \& Jaillard, J. (1978), J. Immunol. Meth. 21, 317-324.

170. Matern, S., Tietjen, K., Matern, H. \& Gerok, W. (1978), in: Enzyme labelled immunoassays of hormones and drugs (Pal, S. B., ed.) Walter de Gruyter, Berlin, New York, pp. 457-467.

171. Engvall, E: \& Ruoslahti, E. (1979), in: Immunoassays in the clinical laboratory (Nakamura, R. M., Dito, W. R. \& Tucker, E. S. eds.), Alan R. Liss, Inc., New York, pp. 89-97.

172. Slightom, E. L. (1978), J. Forensic Sci. 23, 292-303.

173. Oellerich, M., in: Optimierung der Asthma-Therapie mit Theophyllin-Präparaten durch Bestimmung der Blutspiegel. (Wettengel, R., ed.) in prep.

174. Cambiaso, C. L., Leek, A. E., de Steenwinkel, F., Billen, J. \& Masson, P. L. (1977), J. Immunol. Meth. 18, 33-44.

175. O'Sullivan, M. J., Bridges, J. W. \& Marks, V. (1979), Ann. Clin. Biochem. 16, 221-240.

176. Matsuoka, K., Maeda, M. \& Tsuji, A. (1979), Chem. Pharm. Bull. 27, 2345-2350.

177. Kato, N., Naruse, H., Irie, M. \& Tsuji, A. (1979), Anal. Biochem. 96, 419-425.

178. Fateh-Moghadam, A., Neumeier, D. \& Pape, S. (1979), in: Praktische Anwendung des Enzymimmunoassays in der Klinischen Chemie und Serologie (Vogt, W., ed.), G. Thieme Verlag, Stuttgart, 59-65.

179. Tanswell, P., Albert, W., Glatz, C., Treffert, C., Linke, R. \& Staehler, F. (1979), in: Praktische Anwendung des Enzymimmunoassays in der Klinischen Chemie und Serologie (Vogt, W., ed.), G. Thieme Verlag, Stuttgart, 91-97.

180. Kato, K., Umeda, Y., Suzuki, F., Hayashi, D. \& Kosaka, A. (1979), Clin. Chem. 25, 1306-1308.

181. Baqir, Y. A., Ross, P. E. \& Bouchier, I. A. D. (1979), Anal. Biochem. 93, 361-365.
Priv.-Doz. Dr. M. Oellerich Institut für Klinische Chemie Karl-Wiechert-Allee 9 D-3000 Hannover 61 